\title{
Anticoagulant protein S in COVID-19: low activity, and associated with outcome
}

\author{
LAURA ELENA STOICHITOIU ${ }^{1}$, LARISA PINTE ${ }^{1,2}$, MARIUS IOAN BALEA $^{3}$, VALENTIN NEDELCU $^{3}$, \\ CAMELIA BADEA ${ }^{1,2}$, CRISTIAN BAICUS ${ }^{1,2}$ \\ ${ }^{1}$ Colentina University Hospital Bucharest, Department of Internal Medicine \\ ${ }^{2}$ Carol Davila University of Medicine and Pharmacy Bucharest, Department of Internal Medicine Colentina \\ ${ }^{3}$ Colentina University Hospital Bucharest, Department of Pneumology
}

\begin{abstract}
Introduction. COVID-19 disease was associated with both thrombo-embolic events and in-situ thrombi formation in small vessels. Antiphospholipidic antibodies were found in some studies.

Aim. Assessment of protein S activity in patients with COVID-19 as a cause of this prothrombotic state, and of the association of protein $\mathrm{S}$ activity with worse outcome.

Methods. All patients admitted for COVID-19 disease in a university hospital between $15^{\text {th }}$ of May and $15^{\text {th }}$ of July 2020 were prospectively enrolled into this cohort study. Patients treated with antivitamin $\mathrm{K}$ anticoagulants and with liver disease were excluded. All patients had protein S activity determined at admission. The main outcome was survival, while secondary outcomes were clinical severity and lung damage.

Results. 91 patients were included, of which 21 (23.3\%) died. Protein S activity was decreased in $65 \%$ of the patients. Death was associated with lower activity of protein S (median $42 \%$ vs. $58 \%, \mathrm{p}<0.001$ ), and the association remained after adjustment for age, inflammation markers and ALAT. There was a dose-response relationship between protein $\mathrm{S}$ activity and clinical severity (Kendall_tau coefficient $=-0.320, \mathrm{p}<0.001$; Jonckheere-Terpstra for trend: $\mathrm{p}<0.001$ ) or pulmonary damage on CT scan (Kendall_tau coefficient $=-0.290, \mathrm{p}<0.001$; Jonckheere-Terpstra for trend: $\mathrm{p}<0.001)$. High neutrophil count was also independently associated with death $(\mathrm{p}=0.002)$.

Conclusion. Protein S activity was lower in COVID-19 patients, and its level was associated with survival and disease severity, suggesting that it may have a role in the thrombotic manifestations of the disease.
\end{abstract}

Key words: COVID-19, protein S, thrombophilia, thrombosis, neutrophilia.

What is new / What is important:

- COVID-19 is associated with thrombophilia

- Protein $\mathrm{S}$ activity was decreased in most of the patients with COVID-19

- Lower protein $\mathrm{S}$ was associated with death

- Lower the protein S, higher the clinical severity or the pulmonary damage on CT

\section{INTRODUCTION}

Since SARS-CoV-2 pandemic began, it has spread rapidly across the globe, leading to an enormous number of deaths. The clinical spectrum of this disease varies from asymptomatic forms and mild upper respiratory tract disease, to severe cases of pneumonia with associated acute respiratory distress syndrome, in $15 \%$ of the hospitalized patients. Progressive respiratory failure is one of the primary causes of death [1-3]. Post mortem studies have shown, besides a pattern of diffuse alveolar damage and hyaline membranes, characteristic to acute lung injury, also platelet-fibrin thrombi in small arterial vessels. Carsana et al., who analyzed lung tissue samples, reported such thrombi in $87 \%$ of the cases they evaluated, while Ackermann et al. showed that alveolar capillary microthrombi were 9 times more prevalent in patients with Covid-19 than in patients with influenza [2,4]. Likewise, from a clinical point of view, COVID-19 is characterized by broad thromboembolic manifestations, ranging from venous thromboembolism to arterial events [5-7]. One healthcare system from New York reported, in patients under 50 years of age, five cases of acute ischemic stroke associated with COVID-19 over two weeks, while every 2 weeks over previous 12 months, that service has treated, on average, 0.73 patients [8]. A series of 184 patients from ICU showed a cumulative incidence of VTE of $27 \%$ despite 
the fact that all the patients received at least standard thromboprophylaxis dose [9]. Heterogeneous theories and information have been postulated regarding the haemostasis disruption which takes place in COVID-19 and many papers are focusing at present on this subject. But, despite this rising interest, one field has been overlooked and this field is represented by the protein $\mathrm{S}$ and TAM family receptors network, which represent the very core of the balance between "the good inflammation" and "the bad inflammation" [10]. Recently, Lemke and Silverman proposed a theory suggesting that the intense process of blood clotting and the immune hyperreaction seen in patients with COVID-19 may be interlinked and may be the consequence of the dyshomeostasis of the same regulator, protein S [10]. Protein S, besides the well-known anticoagulant function as a cofactor for the activated protein $\mathrm{C}$, possesses another extremely important role, which resides in the activation of the immunosuppressive TAM receptors, their function being essential in preventing a status of hyperinflammation, as the one seen in acute lung injury [10]. Amazingly, there are only sparse and indirect references to the role of the S-protein for the outcome of patients hospitalized with COVID-19. Our aim was to evaluate the role played by protein $\mathrm{S}$ in the severity of the SARS-CoV-2 induced lung lesions and, consequently, to test if protein $\mathrm{S}$ is involved in patients' outcome.

\section{MATERIALS AND METHODS}

\section{SETTING AND PATIENTS}

This was a cohort study in which we prospectively enrolled the patients admitted to the internal medicine, pneumology, and ICU departments of a secondary care university hospital, from $15^{\text {th }}$ of May to $15^{\text {th }}$ of July 2020. All consecutive patients, 18 years or older, were included if they were diagnosed with COVID-19 by a positive polymerase chain reaction test for SARS-CoV-2 tested on nasopharyngeal swabs samples, irrespective of the presence or the absence of the symptoms and their severity when present; this particular situation was due to the fact that, at the beginning of the pandemic, in Romania, every patient with confirmed Covid-19 had to be hospitalized, by law, even though it was asymptomatic. We excluded from the study patients with known congenital or acquired thrombophilia, patients who were receiving anti-vitamin $\mathrm{K}$ anticoagulants at home, and patients with known liver disease or neoplasia.
The study was conducted according to the Declaration of Helsinki, and the protocol was approved by the ethics committee of Colentina University Hospital.

\section{STUDY DESIGN}

The investigative workup was not standardized; it was decided by every participating physician, depending on initial clinical and laboratory particularities in every single patient. However, because the objective of the study was to test if protein $\mathrm{S}$ is involved in the COVID-19 patients' outcome, all patients had blood samples collected at admission, with protein $\mathrm{S}$ being determined in all of them. All patients had chest standard radiographs, while the patients with pulmonary symptoms or signs had chest computer tomographies (CT scan). Besides, in all the patients with abnormalities on the chest radiography, we performed a chest CT scan; if the patient presented no abnormalities on the radiography, we considered that it was no involvement of the lung. If pulmonary symptoms or signs (including lowering of oxygen saturation) appeared during the hospitalization, chest CT scan was performed, and the worst pulmonary damage during hospitalization was considered as part of the outcome.

\section{LABORATORY PROCEDURES}

Protein S was assessed using STA ${ }^{\circledR}$ Max3 machine (Diagnostica Stago, Asnières, France) and ACL 300R Stago Staclot $\AA$ kit (Diagnostica Stago, Asnières, France). STA $®$-Staclot ${ }^{\circledR}$ assay represents a quantitative measurement of the functional protein $S$ activity, based on the principle of Factor Va inhibition by STA ${ }^{\circledR}$ analyzers. The reference range varies with sex, from $60 \%$ to $130 \%$ for females, and from $75 \%$ to $130 \%$ for males. After the adjustment of the values for gender, the cut-off was set at $60 \%$ for all patients.

\section{VARIABLES AND STATISTICAL ANALYSIS}

Database construction and data analysis were performed using SPSS 16.0 software (SPSS, Inc. Chicago, IL). We categorized patients into three groups, to comprise the whole spectrum of clinical severity of the disease, and in 4 groups regarding the extent of lung involvement on CT scan. Concerning the disease severity, we considered mild disease if the patient had no symptoms. Since studies have 
shown that a peripheral oxygen saturation $<90 \%$ was strongly associated with death, independently of age and sex [11], we considered severe disease if the patient had a peripheral oxygen saturation lower than $90 \%$ together with lung involvement on CT scan; moderate disease was considered if the patients fulfilled none of the above mentioned criteria. As to the severity of the disease evaluated by lung involvement on CT scan, we divided the patients into four categories: no lung involvement on CT scan, mild involvement if less than $25 \%$ of the lungs was involved, moderate disease if lung involvement was $\geq 25 \%$ but $<50 \%$, severe disease if lung involvement was $\geq 50 \%$ but $<75 \%$, and very severe disease if lung involvement was $\geq 75 \%$. Categorical variables were reported as frequency and analyzed by Fisher's exact test. Continuous variables that were not normally distributed were reported as median (minimum and maximum) and analyzed with the Mann-Whitney U test and Kendall $\tau$ (Tau) rank correlation. The Jonckheere-Terpstra test was used to assess the trend between protein $\mathrm{S}$ activity level and ordinal outcomes. Protein S levels were adjusted for gender. Because protein $\mathrm{S}$ levels vary with age, liver disease and inflammation, we adjusted for age, ALT, ferritin, $\mathrm{C}$ reactive protein and neutrophil number. In the logistic regression, the variables were selected by the "enter" method, with evolution (death yes/no) as dependent variable. Hypothesis testing was 2-tailed, and statistical significance was defined by $\mathrm{p}<0.05$.

\section{RESULTS}

91 patients were included in the study, of which $70(76.9 \%)$ were discharged, and $21(23.1 \%)$ died. 32 (35.2\%) had mild disease, 22 (24.2\%) had moderate disease, while 36 (39.6) had severe disease. All the 21 patients who died were from the severe disease group.

59 patients $(64.8 \%)$ had a protein S activity lower than normal.

Patients' characteristics, together with the results of the routine tests performed in our patients were presented in Table 1. Patients who died had significantly lower protein S activity. Death was also associated with more advanced age, higher levels of inflammatory markers (neutrophils, $\mathrm{C}$ reactive protein, ferritin) and d-dimers, lower levels of lymphocytes, and feminine gender (when adjusted for age, gender difference disappeared). Fibrinogen and anticoagulant protein $\mathrm{C}$ did not associate with a negative outcome.

Table 1

Patients' characteristics

\begin{tabular}{|c|c|c|c|}
\hline Characteristic & $\begin{array}{c}\text { Survival, N (\%) } \\
70(76.9 \%)\end{array}$ & $\begin{array}{c}\text { Death, N (\%) } \\
21(23.1 \%)\end{array}$ & $\mathbf{p}$ \\
\hline Age, yr & $52(16,91)$ & $68(33,87)$ & 0.007 \\
\hline Sex, F & $35(50.7 \%)$ & $17(81 \%)$ & 0.014 \\
\hline Protein S, \% & $58(18,135)$ & $42(15,91)$ & $<0.001$ \\
\hline Lymphocytes, $/ \mu \mathrm{L}$ & $1410(320,4600)$ & $720(7,2080)$ & $<0.001$ \\
\hline Neutrophils, $/ \mu \mathrm{L}$ & $3380(1030,13560)$ & $11620(220,21810)$ & $<0.001$ \\
\hline Platelets, $\times 10^{3} / \mu \mathrm{L}$ & $224.5(52,711)$ & $242(23,464)$ & 0.875 \\
\hline $\mathrm{LDH}, \mathrm{U} / \mathrm{L}$ & $212(105,3343)$ & $535(326,2024)$ & $<0.001$ \\
\hline $\mathrm{CRP}, \mathrm{mg} / \mathrm{L}$ & $7.2(0.11,341.79)$ & $55(2.96,312)$ & $<0.001$ \\
\hline Ferritin, $\mu \mathrm{g} / \mathrm{L}$ & $265.1(6.31,4613)$ & $1023(102,23436)$ & $<0.001$ \\
\hline Fibrinogen, $\mathrm{mg} / \mathrm{dl}$ & $450(247,793)$ & $516,(110,980)$ & 0.09 \\
\hline d-dimers, & $0.45(0.00,7.28)$ & $2(0.48,21.00)$ & $<0.001$ \\
\hline PT, s & $13.6(11.9,20.2)$ & $14.7(11.5,40.6)$ & 0.189 \\
\hline Troponin, ng/ml & $9.68(5,62.25)$ & $29.4(7,258)$ & $<0.001$ \\
\hline NT-proBNP, pg/ml & $85.4(5,37055)$ & $1260(53,71000)$ & $<0.001$ \\
\hline Protein $\mathrm{C}, \%$ & $105(55,200)$ & $94(16,169)$ & 0.138 \\
\hline TGP, U/L & $22.3(3.1,200.7)$ & $40.1(8.6,230.3)$ & 0.035 \\
\hline Pulmonary disease, $\%$ & $10(0,90)$ & $70(10,95)$ & $<0.001$ \\
\hline
\end{tabular}

Protein $\mathrm{S}$ activity correlated with $\mathrm{SaO}_{2}$ (Kendalltau coefficient $=0.301, \mathrm{p}<0.001)$ and d-dimer levels (Kendall-tau coefficient $=-0.281, \mathrm{p}<0.001$ ).

Protein S activity correlated with the severity of the disease (Kendall_tau coefficient $=-0.320$, $\mathrm{p}<0.001$ ) and with the degree of lung involvement on CT scan (Kendall tau coefficient $=-0.290$, $\mathrm{p}<0.001$ ) (Figures 1 and 2, respectively). JonckheereTerpstra test showed that there was a statistically significant trend towards lower activity of protein $\mathrm{S}$ with a more severe disease $(\mathrm{p}<0.001)$ (Figures 1 and 2, respectively). After adjusting for age, ALT 
(as a liver disease marker) and inflammation variables (C reactive protein, ferritin and neutrophil number), protein $\mathrm{S}$ activity level remained associated with the fatal outcome (Table 2); neutrophil number also remained associated with death. Moreover, neutrophil absolute count was also associated with the severity of the disease (Kendall tau coefficient $=$ $0.388, p<0.001$ ) and the extent of lung involvement (Kendall tau coefficient $=0.458, \mathrm{p}<0.001$ ). The cultures for bacterial organisms remained sterile in these patients with neutrophilia, nevertheless they received antibiotic therapy.

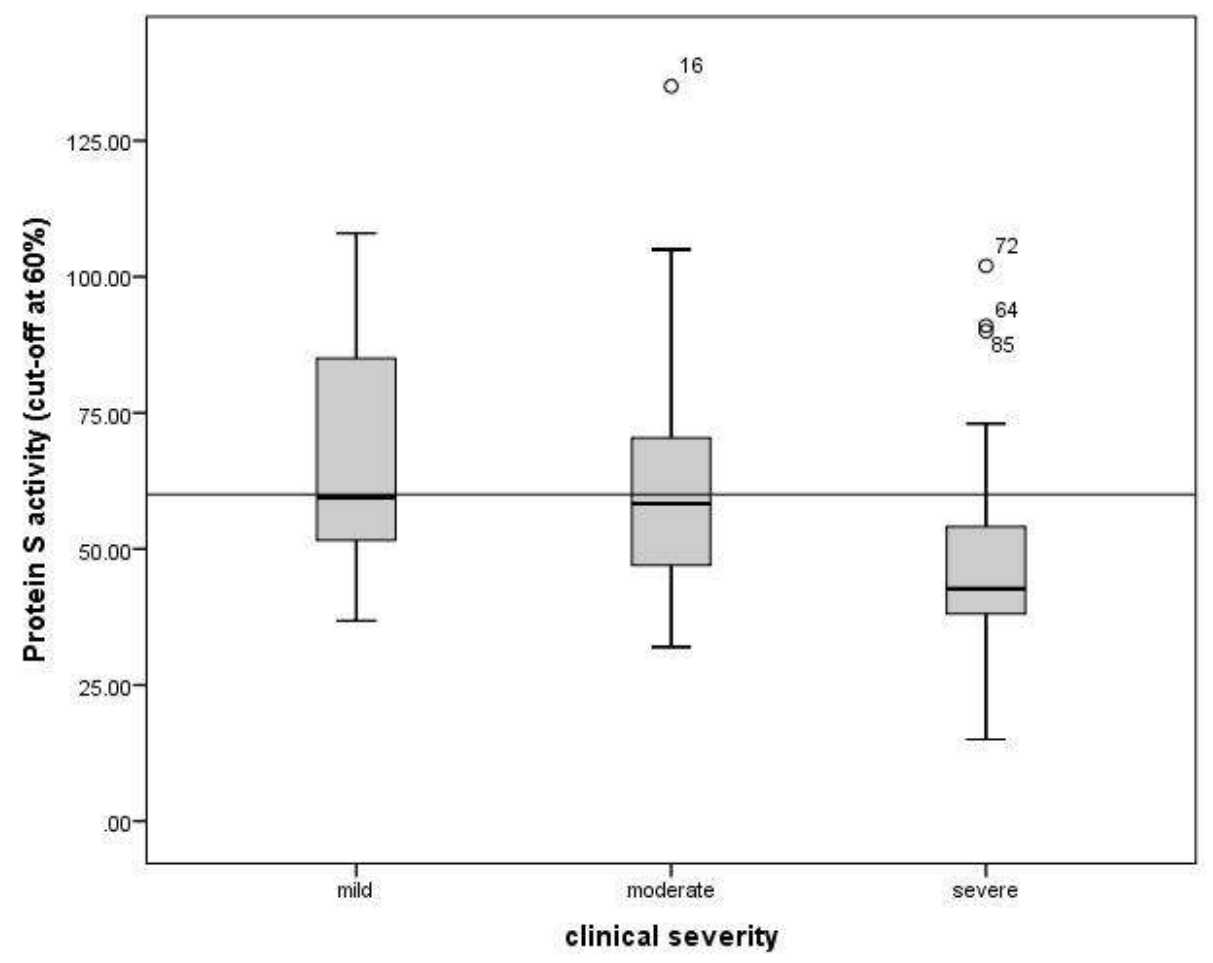

Figure 1. Association of protein S activity with clinical evolution of COVID-19.

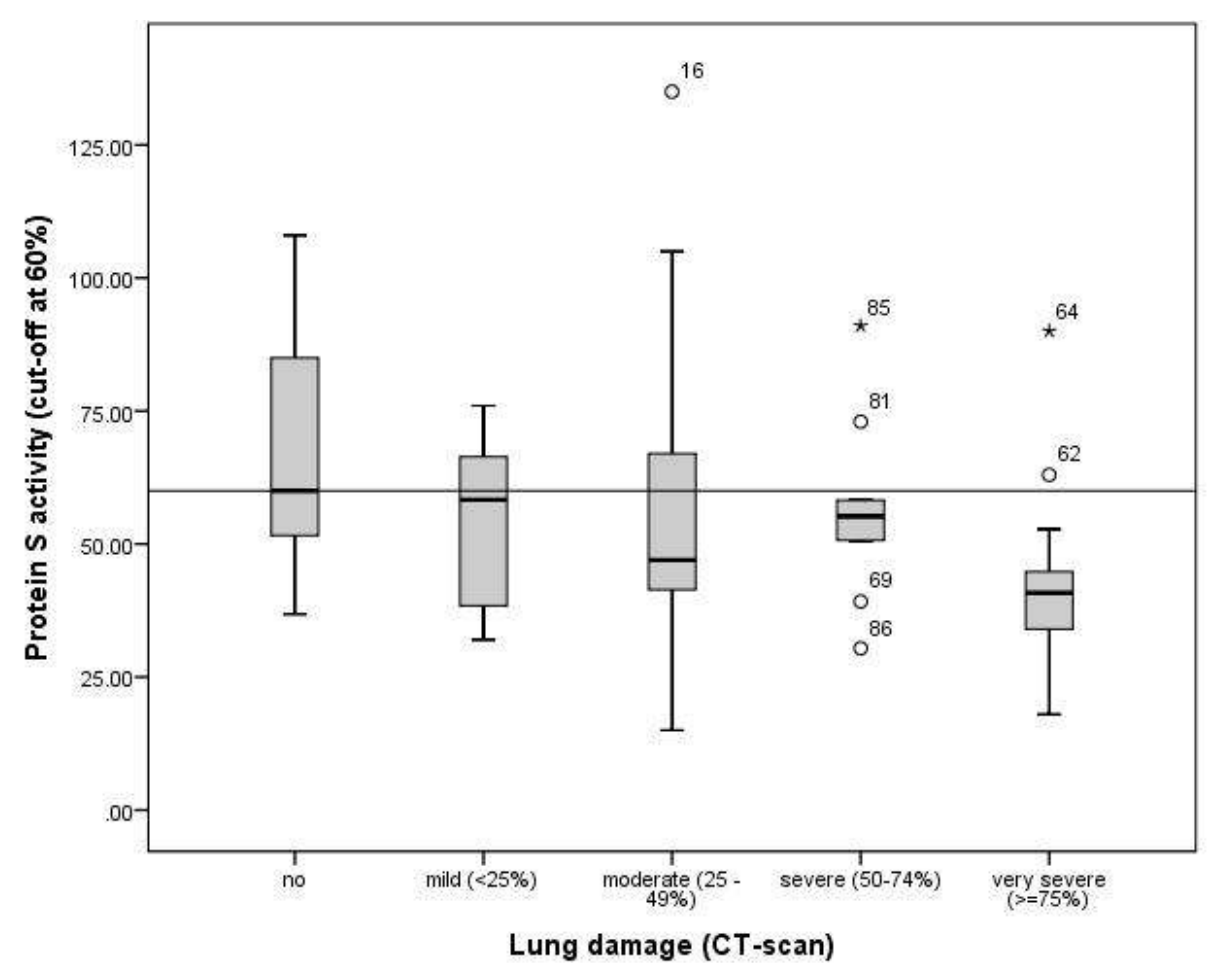

Figure 2. Association of protein S activity with lung damage in COVID-19. 
Table 2

Protein S activity as predictor of death, adjusted for age, inflammation, and liver disease markers (logistic regression)

\begin{tabular}{lccccc}
\hline \multirow{2}{*}{ Variables } & \multirow{2}{*}{ B } & \multirow{2}{*}{ OR } & \multicolumn{2}{c}{$\mathbf{9 5 \%}$ CI for OR } & Upper \\
\cline { 4 - 5 } & & & Lower & 1.008 & 0.845 \\
\hline C reactive protein & -0.001 & 0.99 & 0.990 & 1.001 & 0.311 \\
\hline Ferritin & 0.000 & 1.00 & 1.000 & 1.074 & 0.303 \\
\hline Age & 0.024 & 1.02 & 0.978 & 0.994 & 0.027 \\
\hline Protein S & -0.055 & 0.946 & 0.901 & 1.018 & 0.730 \\
\hline ALT & -0.004 & 0.996 & 0.975 & 1.001 & 0.002 \\
\hline Neutrophils & 0.000 & 1.000 & 1.000 & \\
\hline
\end{tabular}

\section{DISCUSSIONS}

Low protein $\mathrm{S}$ activity was associated with the severity of disease, expressed by clinical parameters or by the degree of lung involvement on CT scan. Besides, low protein S activity was associated with a negative outcome, independently of age, liver disease, or inflammation markers. Neutrophils were also associated with the severity of the disease, the extent of lung involvement, and the outcome. As far as we know, this is the first study that evaluated the involvement of protein $\mathrm{S}$ in COVID-19 patients' outcome.

Current reports indicate that anticoagulation in doses that we are familiar with, may not be adequate in preventing the exuberant thrombotic events seen in COVID-19 patients. Llitjos et al showed that the proportion of VTE was significantly higher in patients treated with prophylactic anticoagulation when compared with the group who received full dose anticoagulation $(100 \%$ vs $56 \%, \mathrm{p}=.03)$ [12]; the fact that $56 \%$ of the patients who developed thromboses were receiving therapeutic anticoagulation, proves that the haemostasis disturbances seen in COVID-19 patients are quite unique.

Currently, the mechanisms involved in this particular type of thrombosis is of highly interest for researchers, because defining them will make us understand this resistance to standard anticoagulation and will certainly change the way in which we will manage the COVID-19 patients. Regarding the mechanisms and factors that enhance this abnormal process of coagulation, several hypotheses have been postulated until now, varying from a local state of pulmonary inflammation and endothelial disfunction, with or without associated antiphospolipid antibodies, to neutrophil extracellular traps, dysregulated complement activation, and dysregulated renin angiotensin system [13]. Recently, a new theory was proposed, which revolves around the natural anticoagulant protein $\mathrm{S}$, and the fact that thromboinflammation may be linked by this protein. Protein S, $60 \%$ percent of whom is bound to the complement factor $\mathrm{C} 4$ binding protein (C4BP), acts as a cofactor for activated protein $\mathrm{C}$ in order to degrade factor $\mathrm{Va}$ and factor VIIIa, thereby modulating the coagulation cascade in an inhibitory fashion [10]. Besides, protein $\mathrm{S}$ is an activating ligand for MER and AXL receptors comprised by the TAM family of receptor tyrosin kinases $[10,14]$. When activated, MER receptors, who are found on the surface of macrophages and other immune cells, are broadly immunosuppressive, and so they temper the production of cytokines, (type 1 interferon, IL-6, TNF), the same cytokines that are linked to cytokine storm and consequently to acute lung injury [10]. So, protein S deficit, by lowering the activation degree of MER receptors, may contribute to the uncontrolled inflammatory status seen in these patients and the consequent organ injury; moreover, this may explain the late onset of clinical deterioration seen in patients with SARS-CoV-2 this delay may correspond to the period of time in which the following events succeed: protein S levels decrease, MER receptors are no longer activated, an exuberant immune reaction develops. The protein $\mathrm{S}$ deficit may be due to the fact that protein $\mathrm{S}$ is depleted in the coagulation process, or may be inherent to the inability of the endothelial cells to produce protein $\mathrm{S}$, due to the endothelitis induced by the infection with SARS-CoV-2 $[15,16]$. C4BP, which binds protein $\mathrm{S}$, is a marker for acute inflammation. Even though we might expect that in inflammatory states, as the ones seen in COVID-19 patients, free protein $\mathrm{S}$ and protein $\mathrm{S}$ activity to be low, due to the high levels of C4BP, previous studies have shown that C4BP levels are not correlated with free protein $\mathrm{S}$ levels $[17,18]$. Protein $\mathrm{S}$ deficiency has also been linked to the presence of antiphospholipid antibodies [18-20], but these results are debatable, since others failed to show such an association [21]. Deficiencies in activating macrophages through MER-protein S complex have been linked to immune hyperactivation and autoimmune diseases [10, 14]; so, is protein $\mathrm{S}$ indeed lowered by the presence of antiphospholipid antibodies, or maybe protein $\mathrm{S}$ 
deficiency induces a form of secondary antiphospholipid syndrome, which may be transitory or not? In our aim to prove that protein S levels are linked to the outcome of Covid-19 patients, we showed that low protein $\mathrm{S}$ levels were linked to the clinical severity of the disease, the lung involvement, and the fatal outcome, thereby fulfilling one of the Hill's criteria for causality, the dose-response relationship [22] the lower the protein $\mathrm{S}$, the more severe the clinical disease and the lung involvement. Besides protein $\mathrm{S}$ levels, an elevated number of neutrophils also associated with the negative outcome; this is in concordance with the results reported in previous studies, which proved that neutrophils are associated with the severity of the disease and the admission to ICU $[23,24]$. Furthermore, neutrophils determine neutrophil extracellular traps (NETs) formation; when NETs' development is not properly inhibited, they initiate and propagate inflammation and thrombosis, not only in arteries and veins, but also in microvasculature, where it can lead to end-organ damage [25-27]. Zuo et al. showed in a recent study that in COVID-19 patients, NETs (cell-free DNA and myeloperoxidase-DNA complexes) strongly correlated with absolute neutrophil count, while C reactive protein, D-dimer and $\mathrm{LDH}$ correlation was not statistically significant [28]. Apparently, protein S and neutrophils, through NETs, share the same double-edged-sword property, the fine line that makes the difference in the patients' outcome, and their association may be the one that imprints the high intensity of the haemostasis disturbances, and the resistance to anticoagulants.

The main limitation of the study resides in the fact that we determined protein S levels only once, at admission, so these patients could have not had protein $\mathrm{S}$ activity lower before. Being a cohort study, in most of the patients there was a clear temporal relationship between the low protein $\mathrm{S}$ activity, which was measured at admission, and the outcome, which occurred afterwards during hospitalization, therefore low protein $\mathrm{S}$ activity appears to be more a cause than an effect.

Besides, we did not evaluate the levels of total and free protein $\mathrm{S}$, nor the presence or absence of antiphospholipid antibodies and other possible contributor to the thrombo-inflammatory state. Moreover, there was no direct proof or reference to the thrombotic state in these patients, as they had not thromboembolic disease diagnosed ante- or post-mortem, which would be the presumed mechanism leading to a severe outcome, although the correlation between protein $\mathrm{S}$ activity and d-dimers could be an argument.

This was a generating hypothesis study. Further research should evaluate the dynamics of protein $\mathrm{S}$, and the relationship with the antiphospholipid antibodies in larger prospective studies, together with the response to higher doses of anticoagulants in such patients.

Introducere: Boala COVID-19 este însoțită atât de evenimente tromboembolice, cât și de tromboze in situ în vasele mici. În unele studii, la aceşti pacienţi s-au găsit anticorpi antifosfolipidici.

Obiectiv: Evaluarea activităţii proteinei S la pacienţii cu COVID-19 ca şi cauză a acestei stări protrombotice şi a asocierii dintre activitatea proteinei $S$ şi deznodământul bolii.

Metode: Au fost incluşi prospectiv în această cohortă toți pacienții cu COVID-19 internaţi într-un spital universitar între 15 mai şi 15 iulie 2020. Au fost excluşi pacienţii cu tratament anticoagulant cu antivitamine $K$ şi cei cu boli hepatice. Tuturor pacienţilor li s-a măsurat activitatea proteinei $S$ la internare. Efectul principal urmărit a fost supravieţuirea, iar cele secundare au fost severitatea clinică şi afectarea pulmonară.

Rezultate: Au fost incluşi 91 de pacienţi, dintre care 21 (23,3\%) au decedat. Activitatea proteinei $S$ a fost scăzută la $65 \%$ dintre ei. Decesul a fost asociat cu o activitate scăzută a proteinei $S$ (mediana $42 \%$ faţă de $58 \%, p<0,001$ ), iar asocierea a rămas semnificativă statistic după ajustarea pentru vârstă, markerii de inflamaţie şi ALAT. A existat o relaţie doză-răspuns între activitatea proteinei $S$ şi severitatea clinică (coefficient Kendall tau $=-0,320, p<0,001$; Jonckheere-Terpstra pentru trend: $p<0,001$ ) sau gradul afectării pulmonare la examenul CT (coeficient Kendall_tau $=-0,290, p<0,001$; Jonckheere-Terpstra pentru trend: $p<0,001$ ). Numărul mare de neutrofile a fost de asemenea asociat independent cu decesul $(p=0,002)$. 
Concluzie: Activitatea proteinei S a fost mai mică la pacienţii cu COVID-19, iar nivelul ei a fost asociat cu supraviețirea şi severitatea bolii, acest fapt sugerând că proteina $S$ ar putea avea un rol în manifestările trombotice ale bolii.

Correspondence to: Laura Elena Stoichitoiu, MD, Colentina University Hospital Bucharest, Department of Internal Medicine, Soseaua Stefan cel Mare 19-21, Sector 2, Bucharest, Romania

E-mail: laura.elena.stoich@gmail.com

Conflicts of interest disclosure: The authors declare that there are no conflicts of interest. The study had no funding.

\section{REFERENCES}

1. CAI A, MCCLAFFERTY B, BENSON J, RAMGOBIN D, KALAYANAMITRA R, SHAHID Z, et al. COVID-19: Catastrophic Cause of Acute Lung Injury. S D Med. 2020; 73(6):252-260.

2. CARSANA L, SONZOGNI A, NASR A, ROSSI RS, PELLEGRINELLI A, ZERBI P, et al. Pulmonary post-mortem findings in a series of COVID-19 cases from northern Italy: a two-centre descriptive study [published online ahead of print, 2020 Jun 8]. Lancet Infect Dis. 2020;S1473-3099(20)30434-5. doi:10.1016/S1473-3099(20)30434-5.

3. CONNORS JM, LEVY JH. Thromboinflammation and the hypercoagulability of COVID-19.J Thromb Haemost. 2020; 18(7):1559-1561. doi:10.1111/jth.14849.

4. ACKERMANN M, VERLEDEN SE, KUEHNEL M, HAVERICH A, WELTE T, LAENGER F, et al. Pulmonary Vascular Endothelialitis, Thrombosis, and Angiogenesis in Covid-19. N Engl J Med. 2020; 383(2):120-128. doi:10.1056/NEJMoa2015432.

5. BILALOGLU S, APHINYANAPHONGS, JONES S, ITURRATE E, HOCHMAN J, BERGER JS. Thrombosis in Hospitalized Patients With COVID-19 in a New York City Health System [published online ahead of print, 2020 Jul 20]. JAMA. 2020; e2013372. doi:10.1001/jama.2020.13372.

6. MIDDELDORP S, COPPENS M, VAN HAAPS TF, FOPPEN M, VLAAR AP, MULLER MCA, et al. Incidence of venous thromboembolism in hospitalized patients with COVID-19 [published online ahead of print, 2020 May 5]. J Thromb Haemost. 2020; doi:10.1111/jth.14888. doi:10.1111/jth.14888.

7. LODIGIANI C, IAPICHINO G, CARENZO L, CECCONI M, FERRAZZI P, SEBASTIAN T et al. Venous and arterial thromboembolic complications in COVID-19 patients admitted to an academic hospital in Milan, Italy. Thromb Res. 2020; 191:9-14. doi:10.1016/j.thromres.2020.04.024.

8. OXLEY TJ, MOCCO J, MAJIDI S, KELLNER CP, SHOIRAH H, SINGH IP, et al. Large-Vessel Stroke as a Presenting Feature of Covid-19 in the Young. $N$ Engl J Med. 2020; 382(20):e60. doi:10.1056/NEJMc2009787.

9. KLOK FA, KRUIP MJHA, VAN DER MEER NJM, ARBOUS MS, GOMMERS DAMPJ, KANT KM, et al. Incidence of thrombotic complications in critically ill ICU patients with COVID-19. Thromb Res. 2020; 191:145-147. doi:10.1016/ j.thromres.2020.04.013.

10. LEMKE G, SILVERMAN GJ. Blood clots and TAM receptor signalling in COVID-19 pathogenesis. Nat Rev Immunol. 2020; 20(7):395-396. doi:10.1038/s41577-020-0354-x.

11. XIE J, COVASSIN N, FAN Z, SINGH P, GAO W, LI G, et al. Association Between Hypoxemia and Mortality in Patients With COVID-19. Mayo Clin Proc. 2020; 95(6):1138-1147. doi:10.1016/j.mayocp.2020.04.006.

12. LLITJOS JF, LECLERC M, CHOCHOIS C, MONSALLIER JM, RAMAKAS M, AUVRAY M, et al. High incidence of venous thromboembolic events in anticoagulated severe COVID-19 patients. J Thromb Haemost. 2020; 18(7):1743-1746. doi:10.1111/ jth.14869.

13. ABOU-ISMAIL MY, DIAMOND A, KAPOOR S, ARAFAH Y, NAYAK L. The hypercoagulable state in COVID-19: Incidence, pathophysiology, and management. Thromb Res. 2020; 194:101-115. doi:10.1016/j.thromres.2020.06.029.

14. LEMKE G. Biology of the TAM receptors. Cold Spring Harb Perspect Biol. 2013; 5(11):a009076. Published 2013 Nov 1. doi:10.1101/cshperspect.a009076.

15. VARGA Z, FLAMMER AJ, STEIGER P, HABERECKER M, ANDERMATT R, ZINKERNAGEL AS, et al. Endothelial cell infection and endothelitis in COVID-19. Lancet. 2020;395(10234):1417-1418. doi:10.1016/S0140-6736(20)30937-5.

16. BURSTYN-COHEN T, HEEB MJ, LEMKE G. Lack of protein S in mice causes embryonic lethal coagulopathy and vascular dysgenesis. J Clin Invest. 2009; 119(10):2942-2953. doi:10.1172/JCI39325.

17. BOULLANGER N, El KOURI D, TROSSAERT M, TRUCHAUD F, TREWICK D, PLANCHON B. Coagulation activation in patients with an inflammatory syndrome: is there a link with acquired protein $\mathrm{S}$ deficiency? Blood Coagulation \& Fibrinolysis: an International Journal in Haemostasis and Thrombosis. 1998 Mar; 9(2):167-171. DOI: 10.1097/00001721-199803000-00007.

18. STAHL CP, WIDEMAN CS, SPIRA TJ, HAFF EC, HIXON GJ, EEVATT BL. Protein S deficiency in men with long-term human immunodeficiency virus infection. Blood. 1993; 81(7):1801-1807.

19. MALIA RG, KITCHEN S, GREAVES M, PRESTON FE. Inhibition of activated protein C and its cofactor protein S by antiphospholipid antibodies. Br J Haematol. 1990; 76(1):101-107. doi:10.1111/j.1365-2141.1990.tb07843.x.

20. SORICE M, GRIGGI T, ARICIERI P, CIRCELLA A, D'AGOSTINO F, RANIERI M, et al. Protein S and HIV infection. The role of anticardiolipin and anti-protein S antibodies. Thromb Res. 1994; 73(3-4):165-175. doi:10.1016/0049-3848(94)90095-7.

21. ERBE M, RICKERTS V, BAUERSACHS RM, LINDHOFF-LAST E. Acquired protein C and protein S deficiency in HIVinfected patients. Clin Appl Thromb Hemost. 2003; 9(4):325-331. doi:10.1177/107602960300900408. 
22. FEDAK KM, BERNAL A, CAPSHAW ZA, GROSS S. Applying the Bradford Hill criteria in the 21 st century: how data integration has changed causal inference in molecular epidemiology. Emerg Themes Epidemiol. 2015; 12:14. Published 2015 Sep 30. doi:10.1186/s12982-015-0037-4.

23. FAN BE, CHONG VCL, CHAN SSW, LIM GH, LIM KGE, TAN GB, et al. Hematologic parameters in patients with COVID-19 infection. Am J Hematol. 2020; 95(6):E131-E134. doi:10.1002/ajh.25774.

24. KONG M, ZHANG H, CAO X, MAO X, LU Z. Higher level of neutrophil-to-lymphocyte is associated with severe COVID-19. Epidemiol Infect. 2020; 148:e139. Published 2020 Jul 9. doi:10.1017/S0950268820001557.

25. TWADELL SH, BAINES KJ, GRAINGE C, GIBSON PG. The Emerging Role of Neutrophil Extracellular Traps in Respiratory Disease. Chest. 2019; 156(4):774-782. doi:10.1016/j.chest.2019.06.012.

26. PORTO BN, STEIN RT. Neutrophil Extracellular Traps in Pulmonary Diseases: Too Much of a Good Thing?. Front Immunol. 2016; 7:311. Published 2016 Aug 15. doi:10.3389/fimmu.2016.00311.

27. PFEILER S, MASSBERG S, ENGELMANN B. Biological basis and pathological relevance of microvascular thrombosis. Thromb Res. 2014; 133 Suppl 1:S35-S37. doi:10.1016/j.thromres.2014.03.016.

28. ZUO Y, YALAVARTHI S, SHI H, GOCKMAN K, ZUO M, MADISON JA, et al. Neutrophil extracellular traps in COVID-19. JCI Insight. 2020; 5(11):e138999. Published 2020 Jun 4. doi:10.1172/jci.insight.138999.

Received $1^{\text {st }}$ August 2020 